Smith's work began in 2005, when Ontario Chief Coroner Barry McLellan struck an international panel of experts to review 45 legal autopsies performed by Smith over a ro-year period commencing in I99I.

The review, released last April, confirmed the worst fears about Smith's work. A panel of 5 forensic pathologists found mistakes had been made in 20 of the 45 cases reviewed. Premier Dalton McGuinty immediately signaled he would call a public inquiry.

Advocates for the wrongly convicted are demanding major reforms to the accrediting procedures for pathologists and the rules under which they give testimony. The Association in Defense of the Wrongly Convicted, which represents several of the men and women convicted in part on Smith's evidence, says it is difficult to estimate the number of potential miscarriages of justice caused by inadequately trained pathologists.

Association lawyer James Lockyer represents William Mullins-Johnson, who spent 12 years in prison for the I993 murder of his 4-year-old niece, who Smith concluded had been sodomized and strangled. Other forensic experts subsequently concluded the girl died of natural causes.

In addition to specific training and accreditation, Lockyer argues that pathologists should be instructed on how to present evidence objectively and how to manage their relationship with police and prosecutors. As was the case with other scientific experts - such as hair and fibre microscopists - pathologists can be made to feel they are part of the prosecution "team" and that they must tailor evidence to help secure a conviction, he adds.

The criminal justice system must also provide the resources to allow accused people to call their own forensic experts to balance the opinions of those employed directly by the state, Lockyer says. "Clearly, like any group that regularly works for government, they are going to suffer from cultural problems. I have always favoured separating [scientific experts and prosecution services] as much as you can." Dan Lett, Winnipeg

DOI:I0.I503/cmaj.07088I

\section{Bernstein bails presidency}

W

eary of serving as the "scapegoat" for researchers who are disgruntled about declining success rates in grant competitions, Canadian Institutes of Health Research (CIHR) President Dr. Alan Bernstein will walk away from the final 3 years of his second term by resigning his post effective Oct. 3 I.

"You don't want to overstay your welcome," said Bernstein, who has been at the CIHR helm for 7 years. "In these leadership positions, you have to be careful to leave at the right time and the longer you are on the job, the more defensive you get of your own track record."

The basic biomedical research community has simmered with discontent as success rates in grant competitions began to drop as a consequence of the federal government having contained the growth rate of the agency's base budget to $5 \%$ or less in each of the past 3 years.

Complaints were few as the overall CIHR pie grew rapidly at the start of the decade from a $\$ 250$ million level in 200I, when the predecessor Medical Research Council was dissolved in favor of an agency with a mandate to expand the ambit of Canadian research beyond basic biomedical science to include 3 other pillars: clinical, population health, and health services and systems research.

But as the CIHR received modest budget increases of $4.4 \%, 2.4 \%$ and $5 \%$, respectively, in the past 3 years (raising the current base budget to $\$ 737$ million), the biomedical research community began grumbling about the extent to which monies were being funneled into the 3 other pillars or being pumped into strategic initiatives in areas of national health need. A review of CIHR's structure, function and processes conducted last year indicated the community wanted to clip the wings of senior management by decentralizing authority to divide the financial pie (CMAJ 2006; I75[8]:857-8). The governing council subsequently agreed to establish such a decision-making committee, comprised primarily of the scientific directors of CIHR's existing I 3 institutes.

It's only natural for such complaints to surface as budgetary pressures increase, Bernstein said. "They want to

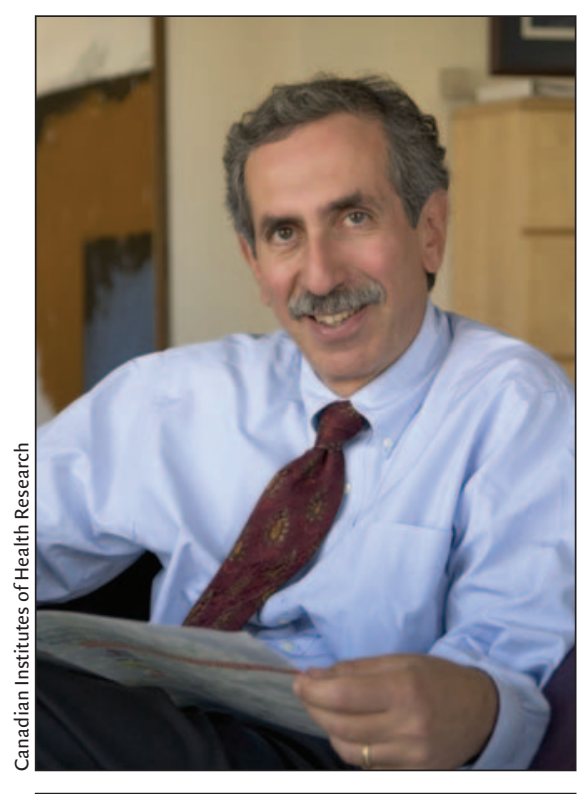

"I've accomplished what I set out to do," CIHR President Dr. Alan Bernstein says while announcing his resignation.

find a scapegoat. That's why I'm paid the big bucks."

There are those within the research community who don't understand that the CIHR has a mandated, legislative responsibility to significantly expand the ambit of its research, as that was the rationale for its creation, Bernstein added. "Some people have difficulty seeing that vision. Fair enough. But that's not CIHR. CIHR has a broader vision."

Bernstein also indicated that his resignation should not be construed as an expression of dissatisfaction with the government's plans to separate the presidency into 2 administrative positions, while appointing more corporate representatives to the governing board (CMAJ 2007;177[I]:2I-2). "I never felt it was a top ro priority in terms of a science and technology policy but I don't object to that." Nor did the government quietly orchestrate his departure. "I've never felt nudged."

Bernstein will not return to the Samuel Lunenfeld Institute, where he earned his scientific stripes through stem cell research. Rather, he'll pursue international career options. "I just turned 60 and I felt I've got another job in me. But I'm not sure what it'll be yet." - Wayne Kondro, CMAJ

DOI:Io.I503/cmaj.0709I4 